\title{
PENGARUH PENGOLAHAN TANAH TERHADAP PERTUMBUHAN, PRODUKSI DAN SERAPAN HARA UBIKAYU (Manihot esculenta Crantz) PADA PERIODE TANAM KE- 2 DI GEDUNG MENENG BANDAR LAMPUNG
}

\author{
Deliyana, Jamalam Lumbanraja, Sunyoto \& M. Utomo \\ Jurusan Agroteknologi, Fakultas Pertanian Universitas Lampung. \\ Jl. Sumantri Brojonegoro No.1 Bandar Lampung 35145 Indonesia \\ Email : deliyana57@gmail.com
}

\begin{abstract}
ABSTRAK
Peningkatan produksi ubikayu umumnya dilakukan melalui dua cara yaitu ekstensifikasi dan intensifikasi. Ekstensifikasi dilakukan dengan penambahan areal panen tetapi sulit dilakukan karena terjadi alih fungsi lahan dan pertambahan penduduk, sedangkan intensifikasi dapat dilakukan dengan cara pengolahan tanah. Penelitian ini bertujuan untuk mengetahui pengaruh sistem pengolahan tanah dan pengendalian gulma yang dapat mempengaruhi pertumbuhan, produksi dan serapan hara serta sistem pengolahan tanah yang menguntungkan petani ubikayu. Penelitian dilaksanakan di Laboratorium Lapang Terpadu dan di Laboratorium Ilmu Tanah, Fakultas Pertanian, Universitas Lampung dari bulan Juni 2014 sampai Juli 2015. Perlakuan disusun dalam Rancangan Acak Kelompok (RAK) non faktorial dengan 4 perlakuan yaitu : OTM (Olah Tanah Minimum); OTM+Herbisida (Olah Tanah Minimum+ Herbisida berbahan aktif Glifosat 2,4- D); OTS (Olah Tanah Sempurna); OTS+Herbisida (Olah Tanah Sempurna+Herbisida berbahan aktif Glifosat 2,4- D); dengan 4 ulangan. Homogenitas ragam diuji dengan uji Bartlet, aditivitas data diuji dengan uji Tukey, dan perbedaan nilai tengah diuji dengan uji Beda Nyata Terkecil (BNT) taraf $5 \%$ serta dilakukan uji korelasi variabel utama yaitu N, P, K. Hasil penelitian menunjukkan bahwa pengolahan tanah minimum dan herbisida meningkatkan pertumbuhan ubikayu paling tinggi dibandingkan pengolahan tanah sempurna + herbisida, olah tanah minimum dan olah tanah sempurna. Sistem olah tanah sempurna + herbisida menghasilkan produksi ubikayu dan jumlah hara terangkut tanaman yaitu N, P dan K serta C- tanaman tertinggi dibandingkan olah tanah minimum + herbisida, olah tanah minimum dan olah tanah sempurna. Olah tanah sempurna dan herbisida lebih menguntungkan dari pada olah tanah sempurna, olah tanah minimum dan olah tanah minimum + herbisida di musim tanam kedua.
\end{abstract}

Kata kunci: Herbisida, olah tanah minimum, olah tanah sempuna, ubikayu

\section{PENDAHULUAN}

Ubikayu merupakan sumber bahan makanan ketiga setelah padi dan jagung. Pada tahun 2009 hasil produksi ubikayu di Provinsi Lampung sebesar 7.569.178 ton, selanjutnya tahun 2010 dan 2011 hasil produksi ubikayu meningkat sebesar 8.637.594 ton dan 9.193.676 ton, tetapi tahun 2012 mengalami penurunan sebesar 8.387.351 ton (BPS, 2013). Sedangkan kebutuhan akan tanaman ubikayu di daerah Lampung adalah 14.424.392 ton (Pusat Data dan Sistem Informasi Pertanian, 2014). Penurunan produksi ubikayu disebabkan oleh alih fungsi lahan dan penerapan teknologi cara becocok tanam yang belum tepat (Badan Pengkajian dan Pengembangan Kebijakan Perdagangan, 2013).

Untuk mengatasi masalah tersebut, peningkatan produksi ubikayu dapat dilakukan melalui dua cara yaitu ekstensifikasi dan intensifikasi. Ekstensifikasi sulit dilakukan karena alih fungsi lahan, sedangkan intensifikasi dapat dilakukan dengan pengolahan tanah dan pola tanam yang sesuai (Rukmana, 1997). Pengolahan tanah adalah suatu proses yang dilakukan untuk mendapatkan keadaan tanah yang baik bagi pertumbuhan tanaman.

Penelitian ini merupakan penelitian lanjutan dari musim pertama tanaman jagung untuk mempelajari pengaruh sistem olah tanah dan herbisida terhadap pertumbuhan, produksi, dan serapan hara tanaman serta mempelajari efisiensi dari pengolahan tanah dan herbisida terhadap tanaman yang berbeda. Hasil penelitian Oktaviansyah (2015) pada tanaman jagung di musim tanam pertama dengan perlakuan dan lahan yang sama menunjukkan bahwa olah tanah minimum+herbisida menghasilkan bobot basah dan bobot kering tanaman jagung serta serapan hara N, P dan $\mathrm{K}$ tertinggi dibandingkan perlakuan olah tanah minimum, olah tanah sempurna dan olah tanah sempurna+herbisida. Hasil analisis usaha tani pada tanaman jagung menunjukkan bahwa olah tanah minimum + herbisida lebih menguntungkan dari pada 
perlakuan lainnya di musim tanam pertama. Tetapi pengaruh perlakuan pengolahan tanah terhadap pertumbuhan dan produksi ubikayu belum banyak dilakukan. Penelitian ini bertujuan untuk mengetahui pengaruh sistem pengolahan tanah dan pengendalian gulma yang dapat mempengaruhi pertumbuhan, produksi dan serapan hara serta sistem pengolahan tanah yang menguntungkan petani ubikayu.

\section{BAHAN DAN METODE}

Penelitian dilakukan pada lahan yang sebelumnya ditanami jagung di Laboratorium Lapang Terpadu, Universitas Lampung. Analisis tanah dan jaringan tanaman dilaksanakan di Laboratorium Ilmu Tanah, Fakultas Pertanian, Universitas Lampung. Penelitian dilakukan pada bulan Juni 2014 - Juli 2015. Alat yang digunakan adalah timbangan, alat tulis, dan alat laboratorium, sedangkan bahan yang digunakan adalah herbisida berbahan aktif Glifosat 2,4- $D$ dengan dosis $4 \mathrm{~L} \mathrm{ha}^{-1}$, sampel tanaman dan tanah, pupuk Urea, TSP, KCL dan Organonitrofos dengan dosis $200 \mathrm{~kg}, 300 \mathrm{~kg}$, $400 \mathrm{~kg}$ dan $10.000 \mathrm{~kg} \mathrm{ha}^{-1}$ serta bahan kimia untuk analisis tanah dan tanaman. Perlakuan disusun dalam Rancangan Acak Kelompok (RAK) non faktorial dengan 4 perlakuan yaitu : OTM (Olah Tanah Minimum); OTM+

Herbisida (Olah Tanah Minimum+Herbisida berbahan aktif Glifosat 2,4- D); OTS (Olah Tanah Sempurna); OTS+Herbisida (Olah Tanah Sempurna+Herbisida berbahan aktif Glifosat 2,4- D) yang diulang 4 kali. Homogenitas ragam diuji dengan uji Bartlet, aditivitas data diuji dengan uji Tukey, dan perbedaan nilai tengah diuji dengan uji Beda Nyata Terkecil (BNT) taraf $5 \%$ serta dilakukan uji korelasi variabel utama yaitu N, P, K. Selanjutnya dilakukan uji ekonomis untuk mengetahui perhitungan terhadap penerimaan dan pengeluaran yang dapat disebabkan oleh pengolahan tanah.

\section{HASIL DAN PEMBAHASAN}

Sifat Kimia Tanah Awal dan Akhir Tanaman Ubikayu. Reaksi tanah (pH) awal percobaan (Tabel 1) semua perlakuan termasuk netral, sedangkan analisis tanah akhir semua perlakuan menjadi agak masam. Hal ini dapat disebabkan oleh curah hujan dan terbawa saat panen. Kandungan P- tersedia tanah akhir tergolong rendah, berbeda dengan analisis tanah awal $\mathrm{P}$ - tersedia pada OTM, OTS dan OTS+H ke kriteria sedang- sangat tinggi (Tabel 1).

Hara makro lain seperti kalium dapat ditukar tanah awal (K-dd) semua perlakuan tergolong rendah, tetapi hasil analisis tanah akhir mengalami peningkatan pada $\mathrm{OTM}+\mathrm{H}$ dan OTS $+\mathrm{H}$ ke kriteria sedang. Hal ini karena bahan organik dapat memperbaiki sifat kimia tanah. Menurut Adnan, dkk., (2012) gulma yang mati terdekomposisi sehingga menjadi tambahan unsur hara yang tersedia dan dapat diserap tanaman.

C- total tanah awal dan akhir semua perlakuan termasuk rendah (Tabel 1). Penurunan kandungan $\mathrm{C}$ total tanah terlihat pada OTM+H dari rendah ke sangat rendah. Hal ini diduga berhubungan dengan kehadiran gulma pada petak perlakuan. Gulma yang mati mengalami pelapukan dan dekomposisi sehingga menjadi tambahan unsur hara untuk C- organik di dalam tanah.

Pertumbuhan Tinggi Tanaman Ubikayu. Perbedaan pengolahan tanah memberikan pengaruh yang nyata terhadap tinggi tanaman ubikayu 9 bulan setelah tanam (Tabel 2). Perlakuan $\mathrm{OTM}+\mathrm{H}$ menghasilkan tanaman tertinggi yang tidak berbeda nyata dengan OTS $+\mathrm{H}$. Hal ini disebabkan oleh pemakaian mulsa dan herbisida. Menurut Hinarti (2012), mulsa dari serasah jagung mengandung $\mathrm{N}$ sebesar 0,98 $\%$. Nitrogen digunakan tanaman untuk pertumbuhan vegetatif (Yuniwati, 2007). Selain itu, menurut Agahiu (2011), penggunaan herbisida lebih efektif untuk mengendalikan gulma.

Produksi Tanaman Ubikayu. Perbedaan pengolahan tanah memberikan pengaruh yang nyata terhadap produksi. Perlakuan OTS+H menghasilkan bobot daging+kulit tertinggi yang tidak berbeda nyata dengan OTM (Tabel 2). Hal ini disebabkan oleh persiapan lahan dapat menunjang pertumbuhan dan perkembangan umbi. Menurut Roja (2009), ubikayu memerlukan tanah yang gembur agar akar tumbuh dan berkembang dengan optimal. Bobot kering daging tanpa kulit ubikayu tertinggi terdapat pada OTS $+\mathrm{H}$ yang berbeda nyata dengan $\mathrm{OTM}+\mathrm{H}$. Rendahnya bobot kering daging pada $\mathrm{OTM}+\mathrm{H}$ disebabkan terjadinya persaingan antara umbi dengan daun. Menurut Roja (2009), persaingan antara umbi dan berangkasan berhenti saat berangkasan mencapai keadaan maksimum. Selain itu, pengolahan tanah tidak berpengaruh nyata terhadap bobot kering kulit, daun dan batang (Tabel 2). Hal ini disebabkan oleh proses penyerapan unsur hara. Menurut Indria (2005) unsur hara yang diserap tanaman dipengaruhi oleh persediaan air dalam tanah sehingga mempengaruhi berat kering tanaman.

Kuantitas Hara Nitrogen (N) Terangkut melalui Panen. Pengolahan tanah berpengaruh nyata terhadap $\mathrm{N}$ terangkut umbi, kulit dan batang tetapi tidak pada daun (Tabel 3). Hara $\mathrm{N}$ tertinggi yang terangkut oleh umbi terdapat pada perlakuan OTS+H yaitu $97,86 \mathrm{~kg} \mathrm{ha}^{-1}$ yang 
berbeda nyata dengan perlakuan lainnya. Hara $\mathrm{N}$ tertinggi yang terangkut kulit terdapat pada OTM yang berbeda nyata dengan perlakuan lainnya. Tingginya $\mathrm{N}$

Tabel 1. Sifat kimia tanah awal pada musim pertama tanaman jagung dan hasil analisis sifat kimia tanah akhir tanaman ubikayu.

\begin{tabular}{|c|c|c|c|c|c|}
\hline \multirow{2}{*}{ Jenis Analisis } & & \multicolumn{4}{|c|}{ Perlakuan } \\
\hline & & OTM & $\mathrm{OTM}+\mathrm{H}$ & OTS & $\mathrm{OTS}+\mathrm{H}$ \\
\hline \multirow{4}{*}{$\mathrm{pH}\left(\mathrm{H}_{2} \mathrm{O}\right)$} & Awal & 6,62 & 6,63 & 7,37 & 7,35 \\
\hline & & $(\mathrm{N})$ & $(\mathrm{N})$ & $(\mathrm{N})$ & $(\mathrm{N})$ \\
\hline & Akhir & 6,02 & 6,06 & 6,03 & 6,4 \\
\hline & & $(\mathrm{AM})$ & $(\mathrm{AM})$ & $(\mathrm{AM})$ & $(\mathrm{AM})$ \\
\hline \multirow{4}{*}{$\begin{array}{l}\text { P- Tersedia } \\
\quad(\mathrm{ppm})\end{array}$} & Awal & 10,49 & 7,47 & 24,28 & 17,82 \\
\hline & & $(\mathrm{S})$ & $(\mathrm{R})$ & $(\mathrm{ST})$ & $(\mathrm{ST})$ \\
\hline & Akhir & 6,41 & 4,84 & 5,82 & 6,62 \\
\hline & & $(\mathrm{R})$ & (R) & (R) & $(\mathrm{R})$ \\
\hline \multirow{4}{*}{$\begin{array}{c}\mathrm{K}-\mathrm{dd} \\
\left.(\mathrm{cmol} \mathrm{kg})^{-1}\right)\end{array}$} & Awal & 0,38 & 0,37 & 0,38 & 0,33 \\
\hline & & $(\mathrm{R})$ & $(\mathrm{R})$ & $(\mathrm{R})$ & $(\mathrm{R})$ \\
\hline & Akhir & 0,38 & 0,47 & 0,37 & 0,40 \\
\hline & & $(\mathrm{R})$ & $(\mathrm{S})$ & $(\mathrm{R})$ & $(\mathrm{S})$ \\
\hline \multirow{4}{*}{$\begin{array}{c}\text { N- Total } \\
(\%)\end{array}$} & Awal & 0,17 & 0,17 & 0,17 & 0,16 \\
\hline & & $(\mathrm{R})$ & $(\mathrm{R})$ & $(\mathrm{R})$ & $(\mathrm{R})$ \\
\hline & Akhir & 0,15 & 0,13 & 0,17 & 0,17 \\
\hline & & $(\mathrm{R})$ & $(\mathrm{R})$ & $(\mathrm{R})$ & $(\mathrm{R})$ \\
\hline \multirow{4}{*}{$\begin{array}{c}\text { C- Total } \\
(\%)\end{array}$} & Awal & 1,59 & 1,6 & 1,77 & 1,81 \\
\hline & & $(\mathrm{R})$ & $(\mathrm{R})$ & (R) & $(\mathrm{R})$ \\
\hline & Akhir & 1,13 & 0,94 & 1,26 & 1,14 \\
\hline & & $(\mathrm{R})$ & (SR) & (R) & (R) \\
\hline
\end{tabular}

Keterangan: OTM (olah tanah minimum), OTM + H (olah tanah minimum + herbisida), OTS (olah tanah sempurna), OTS + H (olah tanah sempurna + herbisida), R (Rendah), S (Sedang), ST (Sangat tinggi), SR (Sangat rendah), N (netral), AM (Agak masam) (Balai Penelitian Tanah, 2005)

Tabel 2. Pengaruh pengolahan tanah terhadap tinggi tanaman, bobot umbi, dan bobot kering tanaman ubikayu

\begin{tabular}{|c|c|c|c|c|c|c|c|}
\hline \multirow{2}{*}{ Perlakuan } & TT & BU & BK Umbi & BK Kulit & BK Daun & BK Batang & Total \\
\hline & $(\mathrm{cm})$ & \multicolumn{6}{|c|}{ 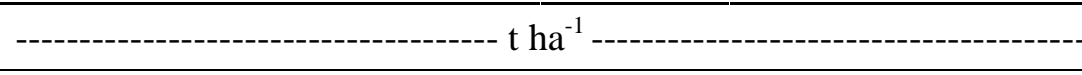 } \\
\hline Olah tanah minimum & $\begin{array}{l}255,60 \\
a b\end{array}$ & $\begin{array}{c}49,58 \\
\mathrm{bc}\end{array}$ & $\begin{array}{c}15,09 \\
a b\end{array}$ & 2,36 & 2,36 & 15,17 & 34,98 \\
\hline $\begin{array}{l}\text { Olah tanah minimum + } \\
\text { Herbisida }\end{array}$ & $\begin{array}{l}273,50 \\
\quad c\end{array}$ & $\begin{array}{c}36,47 \\
\mathrm{a}\end{array}$ & $\begin{array}{l}10,15 \\
\mathrm{a}\end{array}$ & 2,60 & 2,60 & 16,61 & 31,96 \\
\hline Olah tanah sempurna & $\begin{array}{l}247,25 \\
\mathrm{a}\end{array}$ & $\begin{array}{l}45,95 \\
a b\end{array}$ & $\begin{array}{c}15,81 \\
b\end{array}$ & 2,13 & 2,13 & 12,76 & 32,83 \\
\hline $\begin{array}{l}\text { Olah tanah sempurna }+ \\
\text { Herbisida }\end{array}$ & $\begin{array}{l}261,75 \\
\text { bc }\end{array}$ & $\begin{array}{c}57,42 \\
\mathrm{c}\end{array}$ & $\begin{array}{c}19,06 \\
b\end{array}$ & 2,95 & 2,95 & 16,64 & 41,60 \\
\hline BNT $5 \%$ & 14,29 & 10,42 & 5,56 & tn & tn & tn & \\
\hline
\end{tabular}

Keterangan: Kolom yang diikuti dengan huruf yang sama tidak berbeda nyata pada uji BNT taraf $5 \%$ 
Tabel 3. Pengaruh pengolahan tanah terhadap $\mathrm{N}$ yang terangkut pada tanaman ubikayu

\begin{tabular}{lccccc}
\hline \multirow{2}{*}{ Perlakuan } & \multicolumn{5}{c}{ Hara N terangkut $\left(\mathrm{kg} \mathrm{ha}^{-1}\right)$} \\
\cline { 2 - 6 } & Umbi & Kulit & Batang & Daun & Total \\
\hline Olah tanah minimum & $49,81 \mathrm{a}$ & $39,02 \mathrm{~b}$ & $99,15 \mathrm{ab}$ & 88,14 & 276,12 \\
Olah tanah minimum + Herbisida & $47,70 \mathrm{a}$ & $22,18 \mathrm{a}$ & $124,02 \mathrm{c}$ & 105,72 & 299,62 \\
Olah tanah sempurna & $44,27 \mathrm{a}$ & $19,40 \mathrm{a}$ & $77,40 \mathrm{a}$ & 74,50 & 215,57 \\
Olah tanah sempurna + Herbisida & $97,86 \mathrm{~b}$ & $25,17 \mathrm{a}$ & $100,92 \mathrm{~b}$ & 123,75 & 347,7 \\
\hline \multicolumn{1}{c}{ BNT 5\% } & 25,03 & 9,62 & 22,45 & tn
\end{tabular}

Keterangan: Kolom yang diikuti dengan huruf yang sama tidak berbeda nyata pada uji BNT taraf 5\%

yang terangkut sejalan dengan berat kering. Besar kecilnya hasil produksi mempengaruhi hara yang terangkut tanaman. Selain itu, pada batang perlakuan $\mathrm{OTM}+\mathrm{H}$ mengangkut hara $\mathrm{N}$ tertinggi yang berbeda nyata dengan perlakuan lainnya (Tabel 3). Meningkatnya N pada batang dapat disebabkan $\mathrm{N}$ digunakan untuk merangsang pertumbuhan khususnya batang, cabang dan daun (Howeler, 1981). Sedangkan pada daun pengolahan tanah tidak berpengaruh nyata. Hal ini disebabkan kandungan nitrogen mulai berkurang karena sudah ditranslokasikan untuk pertumbuhan generatif (Yurnalis, 2006).

Kuantitas Hara Fosfor (P) Terangkut melalui Panen. Pengolahan tanah berpengaruh nyata terhadap $P$ terangkut umbi, kulit dan daun tetapi tidak pada batang (Tabel 4). Hara P tertinggi yang terangkut oleh umbi terdapat pada perlakuan OTS $+\mathrm{H}$ yang berbeda nyata dengan perlakuan lain. Kandungan $\mathrm{P}$ pada umbi ubikayu sebesar 6-152 mg per 100 gram (Onyenwoke dan Simonyan, 2014). Tingginya hara P pada OTS+H sesuai dengan hasil umbi atau sejalan dengan berat kering tanaman. Hara P diperlukan untuk pembentukan ATP, dan energi dari ATP digunakan untuk membantu dalam serapan K dan P (Salisbury dan Ross, 1992).

Nilai hara $P$ tertinggi yang terangkut daun terdapat pada OTS $+\mathrm{H}$ yang tidak berbeda nyata dengan $\mathrm{OTM}+\mathrm{H}$. Tingginya $\mathrm{P}$ terangkut daun sejalan dengan berat kering pada OTS $+\mathrm{H}$. Besar kecilnya hasil produksi mempengaruhi hara yang terangkut tanaman. Hara P tertinggi yang terangkut pada kulit terdapat pada perlakuan OTS yang berbeda nyata dengan perlakuan lainnya. Rendahnya hara $\mathrm{P}$ terangkut kulit karena $\mathrm{P}$ banyak diserap untuk proses pembentukan umbi sehingga hanya sedikit yang terangkut kulit. Menurut Howeler (1981), hara P digunakan umbi untuk pembentukan dan pembesaran umbi.

Pada batang pengolahan tanah tidak berpengaruh nyata. Hal ini dapat disebabkan antara satu tanaman dengan tanaman lain memiliki kemampuan yang berbeda untuk menyerap unsur hara yang diberikan. Selain itu, banyak faktor yang mempengaruhi serapan $\mathrm{P}$ dalam jaringan tanaman memungkinkan perbedaan kandungan fosfor pada setiap perlakuan (Prawinata, dkk., 1988).

Kuantitas Hara Kalium (K) Terangkut melalui Panen. Perbedaan pengolahan tanah berpengaruh nyata terhadap K terangkut umbi, kulit dan batang tetapi tidak pada daun (Tabel 5). Hara K tertinggi yang terangkut oleh umbi dan kulit terdapat pada perlakuan OTS $+\mathrm{H}$ yang berbeda nyata dengan perlakuan lainnya. Sedangkan pada batang OTS $+\mathrm{H}$ mengangkut hara $\mathrm{K}$ tertinggi yang berbeda nyata antar perlakuan. Besarnya $\mathrm{K}$ terangkut sejalan dengan hasil produksi. Semakin rendah hasil produksi maka semakin rendah $\mathrm{K}$ yang diserap karena $\mathrm{K}$ digunakan untuk proses transportasi dan translokasi asimilat dari daun ke seluruh jaringan tanaman (Sarsini, 2008). Pada daun pengolahan tanah tidak berpengaruh nyata. Hal ini dapat disebabkan $\mathrm{K}$ pada tanaman menurun khususnya di daun sejalan dengan bertambahnya umur tanaman (Hidayat dan Ismunandji, 1978).

Kuantitas Hara Karbon Tanaman Terangkut melalui Panen. Pengolahan tanah berpengaruh nyata terhadap karbon terangkut umbi, kulit dan batang tetapi tidak pada daun (Tabel 6). Nilai karbon tertinggi yang terangkut umbi terdapat pada OTS $+\mathrm{H}$ yang berbeda nyata dengan perlakuan lainnya. Tingginya karbon terangkut umbi sejalan dengan berat kering tanaman. Umbi merupakan tempat menampung sebagian hasil fotosintesis daun yang tidak digunakan oleh tanaman pada fase vegetatif (Roja, 2009). Pada daun perbedaan pengolahan tanah menunjukkan pengaruh yang tidak berbeda nyata. Hal ini dapat disebabkan tanaman menyerap karbon dari daun lewat proses fotosintesis. Salah satu faktor yang mempengaruhi kecepatan laju fotosintesis adalah kadar air. Menurut Lakitan (2010), kekurangan air menyebabkan stomata menutup dan menghambat dalam proses penyerapan karbon sehingga mengurangi laju fotosintesis. 
Tabel 4. Pengaruh pengolahan tanah terhadap P yang terangkut pada tanaman ubikayu

\begin{tabular}{lccccc}
\hline \multirow{2}{*}{ Perlakuan } & \multicolumn{5}{c}{ Hara P terangkut $\left(\mathrm{kg} \mathrm{ha}^{-1}\right)$} \\
\cline { 2 - 6 } & Umbi & Kulit & Batang & Daun & Total \\
\hline Olah tanah minimum & $18,87 \mathrm{ab}$ & $3,30 \mathrm{a}$ & 47,28 & $4,39 \mathrm{a}$ & 73,84 \\
Olah tanah minimum + Herbisida & $12,69 \mathrm{a}$ & $3,54 \mathrm{a}$ & 35,53 & $8,10 \mathrm{~b}$ & 59,86 \\
Olah tanah sempurna & $19,76 \mathrm{~b}$ & $5,95 \mathrm{~b}$ & 38,28 & $2,53 \mathrm{a}$ & 66,52 \\
Olah tanah sempurna + Herbisida & $23,83 \mathrm{~b}$ & $4,27 \mathrm{a}$ & 46,16 & $8,61 \mathrm{~b}$ & 82,87 \\
\hline \multicolumn{1}{c}{ BNT 5\% } & 6,95 & 1,38 & tn & 2,53 \\
\hline
\end{tabular}

Keterangan: Kolom yang diikuti dengan huruf yang sama tidak berbeda nyata pada uji BNT taraf 5\%

Tabel 5. Pengaruh pengolahan tanah terhadap K yang terangkut pada tanaman ubikayu

\begin{tabular}{cccccc}
\hline \multirow{2}{*}{ Perlakuan } & \multicolumn{5}{c}{ Hara K terangkut $\left(\mathrm{kg} \mathrm{ha}^{-1}\right)$} \\
\cline { 2 - 6 } & Umbi & Kulit & Batang & Daun & Total \\
\hline Olah tanah minimum & $34,81 \mathrm{a}$ & $60,47 \mathrm{a}$ & $79,40 \mathrm{a}$ & 37,92 & 212,40 \\
Olah tanah minimum + Herbisida & $28,51 \mathrm{a}$ & $40,98 \mathrm{a}$ & $123,85 \mathrm{~b}$ & 39,69 & 233,03 \\
Olah tanah sempurna & $41,04 \mathrm{ab}$ & $47,67 \mathrm{ab}$ & $116,72 \mathrm{~b}$ & 30,80 & 236,23 \\
Olah tanah sempurna + Herbisida & $52,43 \mathrm{~b}$ & $71,08 \mathrm{~b}$ & $161,04 \mathrm{c}$ & 46,19 & 330,74 \\
\hline \multicolumn{1}{c}{ BNT 5\% } & 15,18 & 19,59 & 27,37 & tn \\
\hline
\end{tabular}

Keterangan: Kolom yang diikuti dengan huruf yang sama tidak berbeda nyata pada uji BNT taraf 5\%

Tabel 6. Pengaruh pengolahan tanah terhadap C yang terangkut pada tanaman ubikayu

\begin{tabular}{lccccc}
\hline \multirow{2}{*}{ Perlakuan } & \multicolumn{5}{c}{ C terangkut $\left(\mathrm{t} \mathrm{ha}^{-1}\right)$} \\
\cline { 2 - 6 } & Umbi & Kulit & Batang & Daun & Total \\
\hline Olah tanah minimum & $6,40 \mathrm{a}$ & $1,91 \mathrm{~b}$ & $6,39 \mathrm{~b}$ & 0,99 & 15,69 \\
Olah tanah minimum + Herbisida & $4,17 \mathrm{a}$ & $1,27 \mathrm{a}$ & $6,35 \mathrm{~b}$ & 1,00 & 12,79 \\
Olah tanah sempurna & $6,45 \mathrm{a}$ & $1,21 \mathrm{a}$ & $4,13 \mathrm{a}$ & 0,82 & 12,61 \\
Olah tanah sempurna + Herbisida & $6,59 \mathrm{~b}$ & $1,57 \mathrm{a}$ & $7,76 \mathrm{c}$ & 1,14 & 17,06 \\
\hline \multicolumn{1}{c}{ BNT 5\% } & 2,34 & 0,52 & 1,32 & tn \\
\hline
\end{tabular}

Keterangan: Kolom yang diikuti dengan huruf yang sama tidak berbeda nyata pada uji BNT taraf 5\%

Tabel 9. Pengaruh pengolahan tanah terhadap $\mathrm{C} / \mathrm{N}$ tanaman Ubikayu dan indeks uji ekonomis pengaruh pengolahan tanah terhadap hasil produksi tanaman ubikayu

\begin{tabular}{lccccc}
\hline \multirow{2}{*}{ Perlakuan } & \multicolumn{3}{c}{ C/N tanaman Ubikayu } & \multirow{2}{*}{$\begin{array}{c}\text { Rasio Hasil Uji } \\
\text { ekonomis }\end{array}$} \\
\cline { 2 - 5 } & Batang & Daun & Kulit & Umbi & \\
\hline Olah tanah minimum & 64,76 & 11,19 & 48,96 & 128,54 & 2,31 \\
Olah tanah minimum + Herbisida & 51,63 & 9,42 & 57,70 & 87,51 & 1,85 \\
Olah tanah sempurna & 53,96 & 11,01 & 63,15 & 145,71 & 2,14 \\
Olah tanah sempurna + Herbisida & 77,71 & 9,17 & 62,80 & 86,35 & 2,63 \\
\hline
\end{tabular}

Karbon tertinggi yang terangkut batang terdapat pada OTS+H yang berbeda nyata dengan perlakuan lainnya (Tabel 6). Tingginya karbon terangkut batang dibandingkan jaringan lain disebabkan oleh biomassa berpengaruh terhadap jumlah karbon yang tersimpan. Menurut Hairiah dan Rahayu (2007), laju pertumbuhan 
dan umur tanaman dapat meningkatkan jumlah karbon tersimpan.

Nisbah $\mathrm{C} / \mathrm{N}$. C/N tertinggi pada batang terdapat pada OTS $+\mathrm{H}$, sedangkan $\mathrm{C} / \mathrm{N}$ terendah pada batang yaitu OTM+H (Tabel 9). $\mathrm{C} / \mathrm{N}$ pada batang lebih rendah dibanding umbi karena nitrogen yang berada pada batang sebesar $1,3 \%$ lebih besar dari pada umbi sebesar $0,3 \%$ dari berat kering tanaman (IFOAM, 2013). Nilai C/N umbi tertinggi terdapat pada OTS (Tabel 10). Tingginya $\mathrm{C} / \mathrm{N}$ umbi dapat disebabkan umbi ubikayu mengandung 40\% karbon dan 0,5\% dari total nitrogen (Anunputtikul dan Rodtong, 2007). Sedangkan pada daun, nilai C/N tertinggi pada OTM. Nilai $\mathrm{C} / \mathrm{N}$ daun ubikayu setiap perlakuan berkisar antara 9-11.

Hal ini sesuai dengan kriteria IFOAM (2013), bahwa $\mathrm{C} / \mathrm{N}$ daun sekitar 12 dan daun mengandung nitrogen yang tinggi yaitu $4 \%$ dari bahan kering. Pada kulit, C/N tertinggi terdapat pada OTS dan $\mathrm{C} / \mathrm{N}$ terendah di OTM. Hal ini dapat disebabkan pengembalian bahan organik seperti sisa panen yang belum matang. Menurut Indranada (1994) sisa panen yang masih segar mengandung $\mathrm{C} / \mathrm{N}$ tinggi dan menyulitkan saat dekomposisi.

Hubungan Hara Terangkut N, P dan K pada Tanaman Ubikayu. Jumlah hara N, P dan K yang terangkut pada setiap perlakuan berbeda- beda. Perlakuan yang banyak mengangkut nitrogen selama pertumbuhan yaitu OTM $+\mathrm{H}$ dan OTS $+\mathrm{H}($ Gambar 1B dan 2A). Hara P banyak terangkut pada OTM, OTS dan OTS $+\mathrm{H}$ (Gambar 1A, 2A dan 2B). Hara K tertinggi yang terangkut tanaman terdapat pada OTS $+\mathrm{H}$ (Gambar 2A), sedangkan jumlah karbon tertinggi yang terangkut berada pada OTM (Gambar 2A).

Hasil uji ekonomis yang dilakukan, OTS $+\mathrm{H}$ memiliki rasio tertinggi dari pada perlakuan lainnya sebesar 2,63 dan diikuti dengan OTM, OTS dan OTS+H yaitu 2,31,2,14 dan 1,85 (Tabel 10). Dengan demikian apabila dilakukan usaha budidaya ubikayu, maka OTS+H lebih menguntungkan secara ekonomi dari pada perlakuan lainnya. Hal ini dikarenakan ubikayu memerlukan kondisi tanah yang gembur untuk pertumbuhan dan perkembangan umbi.
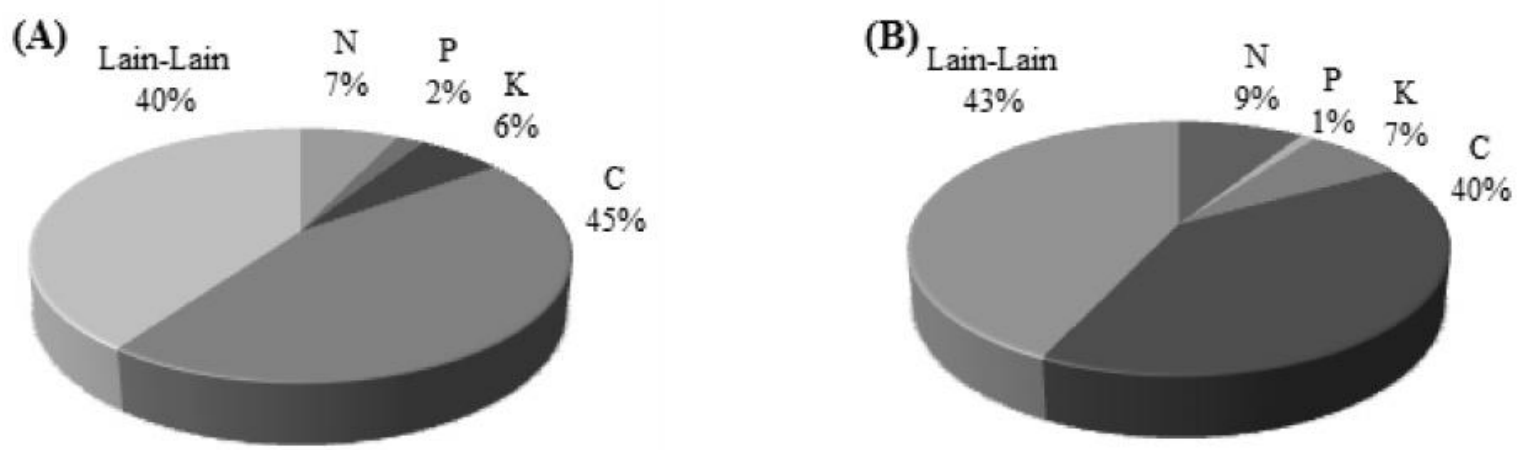

Gambar 1. Jumlah hara terangkut (persen hara terangkut N, P, K dan C) pada (A: perlakuan Olah Tanah Minimum (OTM), B: Olah Tanah Minimum + Herbisida $(\mathrm{OTM}+\mathrm{H})$
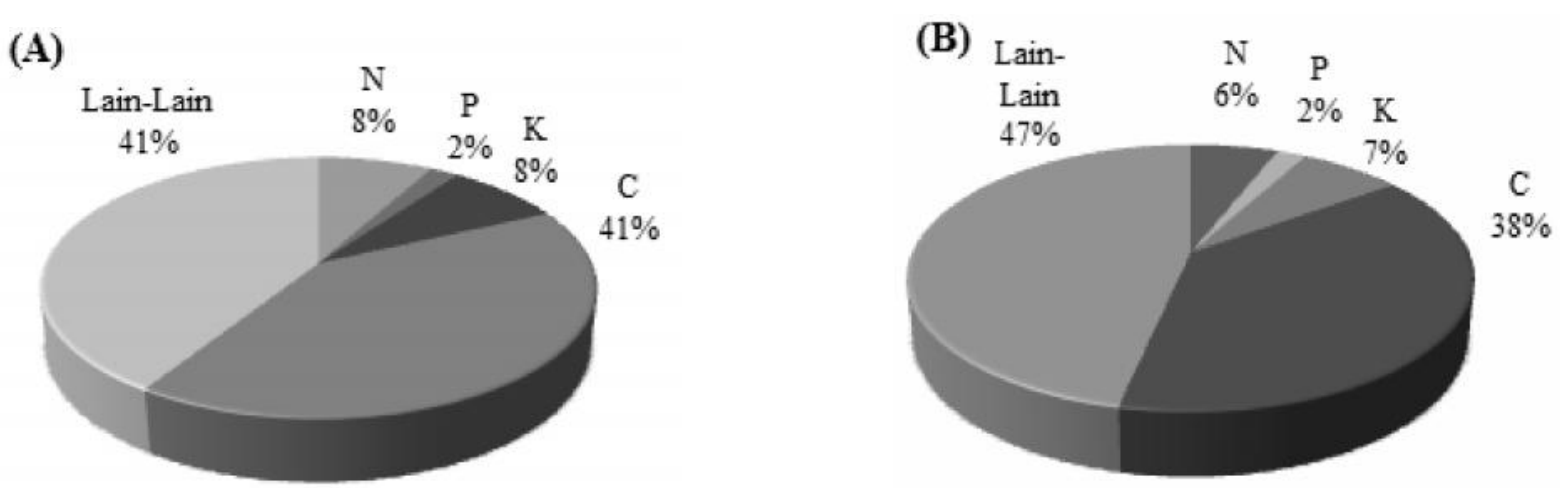

Gambar 2. Jumlah hara terangkut (persen hara terangkut N, P, K dan C) pada (A: perlakuan Olah Tanah Sempurna + Herbisida $(\mathrm{OTS}+\mathrm{H})$, B: Olah Tanah Sempurna (OTS) 


\section{KESIMPULAN}

Dari hasil penelitian disimpulkan bahwa OTM+H meningkatkan pertumbuhan ubikayu paling tinggi dibandingkan OTS $+\mathrm{H}$, OTM dan OTS. OTS $+\mathrm{H}$ menghasilkan produksi ubikayu dan jumlah hara terangkut tanaman yaitu $\mathrm{N}, \mathrm{P}$ dan $\mathrm{K}$ serta $\mathrm{C}$ - tanaman tertinggi dibandingkan OTM $+\mathrm{H}$, OTM dan OTS. $\mathrm{OTS}+\mathrm{H}$ lebih menguntungkan petani dari pada perlakuan OTS, OTM dan OTM+H di musim tanam kedua.

\section{DAFTAR PUSTAKA}

Adnan, H. dan Manfaraziah. 2012. Aplikasi beberapa dosis herbisida Glifosat dan Paraquat pada sistem tanpa olah tanah (TOT) serta pengaruhnya terhadap sifat kimia tanah, karakteristik gulma dan hasil kedelai. J. Agrista 16(3): 135-145.

Agahiu, A.E., U.E. Udensi., G. Tarawali., B. C. Okoye., R.O. Ogbuji, dan K.P. Baiyeri. 2011. Assessment of weed management strategies and intercrop combinations on cassava yield in the middle belt of Nigeria. African J. Agricultural. 6(26): 5729-5735.

Anunputtikul, W. dan S. Rodtong. 2007. Laboratory Scale Experiments for Biogas Production from Cassava Tubers. As. J. Energy Env. 08(01): 444453.

Badan Pengkajian dan Pengembangan Kebijakan Pedagangan. 2013. Analisis kebijakan impor komoditas food additives and ingredients dalam mengurangi defisit neraca perdagangan. Buletin pusat kebijakan perdagangan luar negeri. Jakarta. $40 \mathrm{hlm}$.

Balai Penelitian Tanah. 2005. Petunjuk Teknis Analisis Kimia Tanah, Tanaman, Air dan Pupuk. Balai Penelitian Tanah. Bogor. $136 \mathrm{hlm}$.

BPS. 2013. Produksi singkong di Lampung. Available online at www.bps.go.id., [16 November 2014].

Hinarti, W. O., L. O.Safuan, dan A. Bahrun. 2012. Produksi tanaman jagung dengan pemberian bahan organik dan mulsa pada lahan kering. J. Agronomi. 1(1): 79-85.

Howeler. 1981. Mineral Nutrition and Fertilization of Cassava. CIAT. Columbia. $50 \mathrm{hlm}$.
IFOAM. 2013. The process of composting. Training Manual on Organic Agriculture in the Tropics. 8 hlm.

Indranada, H. 1994. Pengelolaan Kesuburan Tanah. Jakarta. Bumi Aksara. 100 hlm.

Indria, A.T. 2005. Pengaruh sistem pengolahan tanah dan pemberian macam bahan organik terhadap hasil kacang tanah. Skripsi. Universitas Sebelas Maret. Surakarta. $44 \mathrm{hlm}$.

Hairiah, K. dan S. Rahayu. 2007. Pengukuran karbon tersimpan di berbagai macam Penggunaan Lahan. World Agroforestry Center- ICRAF. Bogor. $110 \mathrm{hlm}$.

Hidayat dan Ismunadji. 1978. Pengaruh Pemupukan Nitrogen Melalui Tanah dan Daun Terhadap Pola Serapan Unsur Hara dan Produksi Kedelai. J. Fisiologi. (9): 267-280.

Lakitan, B. 2010. Dasar-Dasar Fisologi Tumbuhan. Jakarta. Raja Grafindo. 205 hlm.

Roja, A. 2009. Ubikayu:Varietas dan Teknologi Budidaya. Balai Pengkajian Teknologi Pertanian (BPTP). Sumatera Barat. $15 \mathrm{hlm}$.

Rukmana, R. 1997. Budidaya Ubikayu dan Pascapanen. Kasinius. Yogyakarta. $77 \mathrm{hlm}$.

Salisbury, F.B and C. Ross. 1992. Plant Physiology. Fourth Edition. Belmont, CA: Wadsworth, Inc. $682 \mathrm{hlm}$.

Sarsini, H. 2008. Pengaruh pengolahan tanah dan pupuk $N$ serta pupuk kandang terhadap serapan $C a$, $S$ dan kualitas hasil kacang tanah pada alfisols. Skripsi. Universitas Sebelas Maret. Surakarta. $88 \mathrm{hlm}$.

Sembiring, L., A. Kelin, dan Salimah. 2013. Analisis Pengaruh Input Produksi terhadap Produksi Usahatani Ubikayu di Desa Sukasari Kecamatan Pegajahan Kabupaten Serdang Bedagai. USU- Press. Medan. 13 hlm.

Yuniwati, E.D. 2007. Pengaruh pemupukan, jarak tanam dan varietas pada budidaya ubikayuuntuk pakan ternak. Wishnuwardana. Malang. $18 \mathrm{hlm}$.

Yurnalis. 2006. Pengaruh aplikasi pupuk organik dan pupuk anorganik terhadap pertumbuhan, produksi serta mutu benih kacang tanah (Arachis hypogaea L.). Tesis. Institut Pertanian Bogor. $59 \mathrm{hlm}$. 